\title{
ROUTINE INSPECTION EFFORT REQUIRED FOR VERIFICATION OF A NUCLEAR MATERIAL PRODUCTION CUTOFF CONVENTION
}

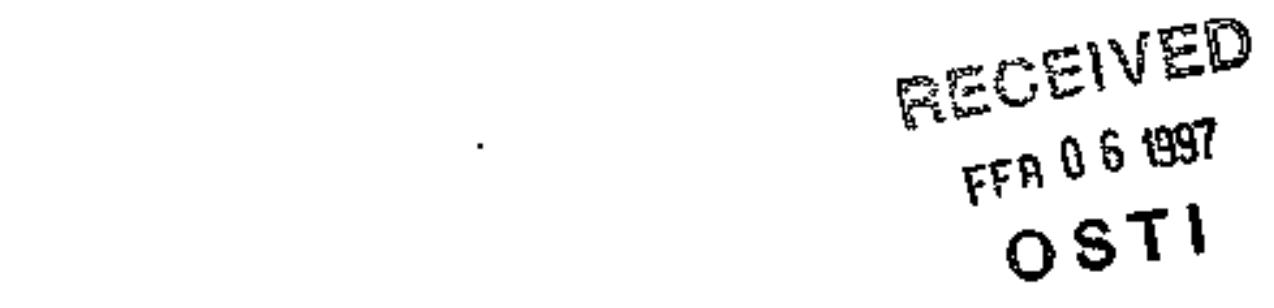

D. Dougherty, A. Famberg, J. Sanborn, J.Allentuck, and C.Sun

DISTRIBUTION OF THIS DOCUNIENT IS UNHMITED

November 1996

SAFEGUARDS, SAFETY, AND NONPROLIFERATION DIVISION

DEPARTMENT OF ADVANCED TECHNOLOGY

Brookhaven Notiondi Laboralory

Butcining 197C

P.O. Box 5000

Upton, Now York 11973-5000 


\section{DISCLAIMER}

Portions of this document may be illegible in electronic image products. Images are produced from the best available original document. 


\section{ROUTINE INSPECTION EFFORT REQUIRED FOR VERIFICATION OF A NUCLEAR MATERIAL PRODUCTION CUTOFF CONVENTION}

D. Dougherty, A. Fainberg, J. Sanborn, J.Allentuck, and C.Sun 


\section{DISCLAMER}

This report was prepared as an account of work sponsored by an agency of the Unlted States Govemment. Neither the United States Govermment nor any agency thereof, or any of their employess, makes any warranty, express or impled, or assumes any legal tiability or responsibility for the accuracy, completeness, or usefulness of any trformatlon, apparatus, product, or process fisclosed, or represents that its use woudd not infiringe privately owned rights. Peference herein to any specific commercial prochuet, process, or service by trade name, tradamark, manufacturer, or otherwise, does not necessarily constitute or imply the enforcement, recommindation, or favoring by the United States Government or any agancy thereof. The views and oplnions of authors expressed herein do nol necessarly slate or reflect those of the United States Govemment or any agency thereof. 


\title{
ROUTINE INSPECTION FFPORT REQUIRED \\ FOR VERIFICATION OF A NUCLEAR MATERIAL PRODUCTION \\ CUTOFF CONVENTION
}

\author{
TABLE OF CONTENTS
}

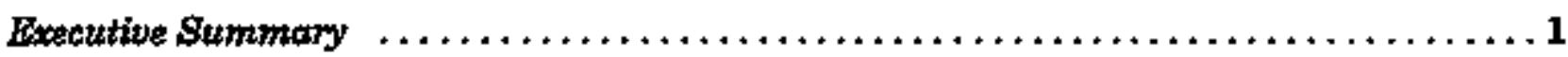

1. Intraduction $\ldots \ldots \ldots \ldots \ldots \ldots \ldots \ldots \ldots \ldots \ldots \ldots \ldots \ldots \ldots, \ldots \ldots \ldots \ldots \ldots, 2$

2. Cutoff Convention Options for Routine Verification $\ldots \ldots \ldots \ldots \ldots \ldots \ldots \ldots, \ldots$

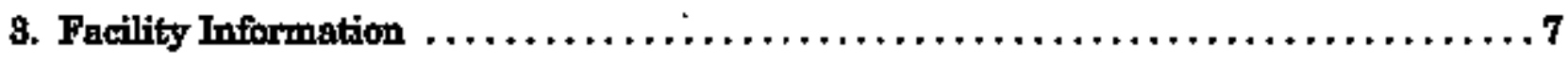

4. Facility Inspection Effort Characterization $\ldots \ldots \ldots \ldots \ldots \ldots \ldots \ldots \ldots, 7$

5. Overall Inapection Effort for Cutoff Convention Verification: BNL Estimate ........9

6. Comparieon of Inspection Effort Estimates $\ldots \ldots \ldots \ldots \ldots \ldots \ldots \ldots \ldots \ldots \ldots$

7. Opportunities for Economizing on Inspection Resources $\ldots \ldots \ldots \ldots \ldots \ldots \ldots \ldots 12$

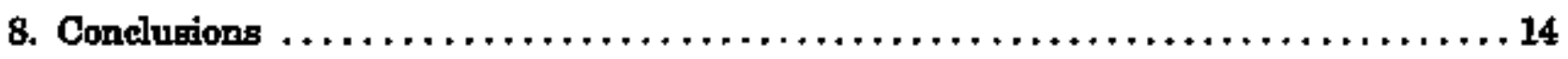

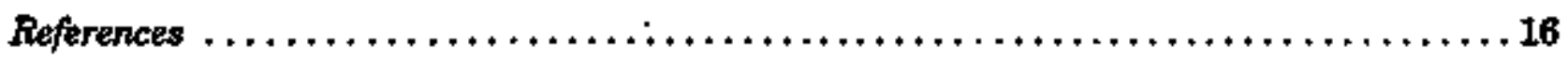

Additional Reading $, \ldots \ldots \ldots \ldots \ldots \ldots \ldots \ldots \ldots \ldots \ldots \ldots \ldots, \ldots \ldots \ldots$

Appendices

Appendix A $\ldots \ldots \ldots \ldots \ldots \ldots \ldots \ldots \ldots \ldots \ldots \ldots \ldots \ldots \ldots \ldots \ldots \ldots \ldots \ldots \ldots, 22$

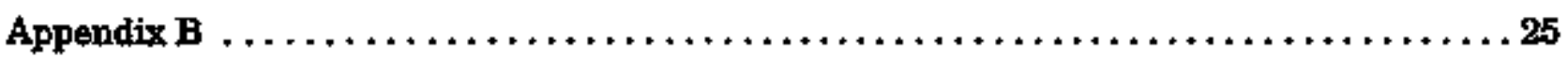




\section{TABLE OF CONTENTS \\ (continued)}

Tables

1. Inspection Gifort Estimates for Each Veriflcation Option \& Numbers of

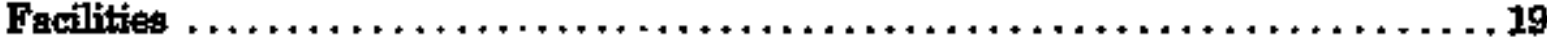

2. Facilities to Be Routinely Verified Under Cutoff Convention Options $\ldots \ldots \ldots \ldots 20$

3. Facility Inspection Effort Values: PID $\ldots \ldots \ldots \ldots \ldots \ldots \ldots \ldots \ldots \ldots \ldots \ldots, \ldots \ldots$

B-1 Inepection Effort Estimates for Each Verification Option \& Numbers of

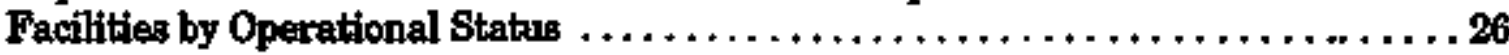

B-2 Inspection Bffort Estimates for Each Verification Option \& Numbers of Facilities by Operational Status for Israel $\ldots \ldots \ldots \ldots \ldots \ldots \ldots \ldots \ldots \ldots \ldots 27$

B-3 Inspection Effort Estimates for Each Verification Option \& Numbers of Facilities by Operational Status for India $\ldots \ldots \ldots \ldots \ldots \ldots \ldots \ldots \ldots \ldots \ldots, 28$

B-4 Inspection Effort Estimates for E⿱ach Verification Option \& Numbers of Facilities by Operational Status for Pakistan

B-5 Inspection Effort Estimates for Each Verification Option \& Numbers of Facilities by Operational Status for USA

B-6 Inspection Effort Estimates for Each Verification Option \& Numbers of Facilities by Operational Status for United Kingdom $\ldots \ldots \ldots \ldots \ldots \ldots \ldots \ldots$.91

B-7 Inspection Effort Estimates for Each Verification Option \& Numbers of Facilitiea by Operational Status for France $\ldots \ldots \ldots \ldots \ldots \ldots \ldots \ldots \ldots \ldots, 32$

B-8 Inspection Effiort Estimates for Fach Verification Option \& Numbers of Facilities by Operational Statur for Russia $\ldots \ldots \ldots \ldots \ldots \ldots \ldots \ldots \ldots \ldots 38$

B-9 Inspection Effort Estimates for Each Verification Option \& Numbers of Facilities by Operational Status for China (PRC) 


\section{Executive Summary*}

Fistimatee of the inspection effort to verify a Nuclear Material Cutoff Convention are presented based on: (1) a database of abont 875 facilities in a total of oight states, i.e., the five nuclear-weapons states and three "threshold" states; (2) typical IAEA experfence for specific factlity types, (3) a set of three options starting with fall IAFA safeguarda and, (4) estimates of "challenge" inspection to investigate/detect undeclared activities.

Three routine verification options are considered. In Option 1, all peaceful nuclear activities would be declared and verified as in non-nuclear weapons states party to the Non-Proliferation Treaty. In Option 2, declarations and verifications would be restricted to enrichment and reproce日ging plants and to facilities storing or processing the produced fisgile matorial. In Option 3, declarations would cover all nuclear facilities but verifications would focus on production at enrichment and reprocessing plants and on the disposition of the firgile material produced.

To account for the likelihood that non-routine inspection procedures will be included to provide a mechanigm to pursue concerns about non-compliance, estimates for " "challenge" or "undeclared site" inspection effort are aleo included. It is expected that these estimates would be simply added to those for routine inspection since the nonroutine (challenge) inspection regime is expected to be independent of that for routine inspections. Challenge inspection effort estimates were based on certain specific assumptions derived from both IAEA Special Inspection procedures and the far more detailed Challenge Inspection procedures contained in the Chemical Weapons Convention. The report does not assess the adequacy of any of these options.

The computed effort ralues associated with the three routine verification options are about 35,000 person days of inspection effort (PDI), 29,000 PDI, and 10,000 PDI, respectively, which can be compared with the total of 8,200 PDI expended by the IAEA Department of Safeguards in 1998. (The 1998 budget of the Depertment of Safeguards was ahout $\$ 65$ million, plus about $\$ 6$ million in extra budgetary resources).

Uncertainties attached to the effort estimates spring from several sources: For example, ahout $60-75 \%$ of the effort for each option is attributable to the 19 large-gcale reprocessing plants aeaumed to be in operation in the ejght states; it is likely that some of these will be shut down by the time the convention enters into force. Another important question involving about one-third of the overall effort is whether Evratom inspections in France and the U.KR could obviate the need for full-scale LARA inspections at these facilities. Finally, the database does not yet contain many small-scale and military-related facilities. The results are, therefore, not presented as predictions but as the consequences of alternative assumptions.

Despite the preliminary nature of the eatimates, it is clear that a broad application of NPT-like safeguards to the eight states would require dramatic increases in the IAFA's safeguards budget. It is alao clear that the major component of the increased inspection effort would occur at large reprocessing plante (and associated plutonium facilities). Therefore, significantly bounding the increased effort requires a limitation on the inspection effort in these factlity types.

\footnotetext{
"This work was performed unier the auspices of the U.S. Department of Energy Contract Number DE-AC02-76CHOOO16.
} 


\section{Introduction}

On 27 September 1998, President Clinton proposed " ... a multilateral convention prohibiting the production of highly enriched uranium or plutonium for nuclear explosives purposes or outside of international safeguards." The UN General Assembly subsequently adopted a resolution recommending negotiation of a nan-discriminatory, multilateral, and internationally and effectively vertilable treaty (hereinafter referred to as "the Cutoff Convention") banning the production of fissile material for nuclear weapons. The matter is now on the agenda of the Conference on Disarmament, although not yet under negotiation.

This accord would, in effeet, place all fiesile material (defined as highly enriched uranium and plutonium) produced after entry into force (EIF) of the accord under international safeguards. "Production" would mean separation of the material in question from radioactive fission products, as in spent fael reprocessing, or enrichment of uranium above the 20\% level, which defines highly enriched uranium (HEU). Facilities where such prodnction could occur would be safeguarded to verify that either such production is not occurning or that all material produced at these facilities is maintained under safeguards.

Material already produced under weapona programs would be "grandfathered" and maintained as not aubject to safeguards, although some nuclear weapon states may voluntarily place excess nuclear material from their weapons stockpile under aafeguards. The US is already doing this.

The LARA is expected to play a key role in the verification regime under the Cutoff Convention. It is assumed that existing comprehensive IAFA asfeguards arrangements for non-nuclear-weapons atates (NNWSs) would essentially meet the verification requirements of the Cutoff Convention, so that the new verification requirements would apply mainly to the nuclear-weepons states and the so-called "threshold states" which are considered to be weapons capable. Thus this paper focuses on eight stateg: the U.S., Russia, China, the U.K, France, India, Pakiaten, and Iarael ((0-8). The firat five statea are the nuclear wrapons states (P-5); the last three are the threshold statee (T-9).

This new set of International safeguards would presumably be applied by the International Atomic Energy Agency (IAFA), just as safeguards are currently applied under extant international agreements, including the Nuclear Nonproliferation Treaty (NPT) and a large number of bilateral and multilateral nuclear agreements between the IAEA and many individual states.

Verification requirements for the G-8 may well be gomewhat different than undex the NPT and its main implementation model, IAEA document INFCIRC/153 ${ }^{\text {(1) }}$. For example, since the Fissile Material Cutoff Treaty (FMCT) would have as its goal the capping of weapons stockpiles among atates that already possess nuclear weapone it would not be necessary to be concerned with diversion of emounts as low as 1 signifficant quantity (SQ). Establiahing a higher figure could enable the regime to meet ita verification requirements, which might not be the case otherwise since many active reproceseing and any HEU enrichment facilities in at least some of the nuclear weapon states could not have their flow and inventory verified to the 1 SQ level for a number of tochnical reasons. 
This peper provides estimates of the inspection effort that would be required under a cutoff convention for routine verification activities of declared facilities and challenge inspections for undeclared sites. For routine verification, three options are coneidered. Challenge ingpection can be applied to any of the three optione.

The estimater are based on a database of about 875 facilities in the eight atates. The inspection effort estimates ehould be regarded as preliminary for several reason. First, the verification options themselves are not yet clearly defined. Second, the operational status of aome important facilities is uncertain at present and cannot be predieted at the time of the Convention's entry-into-force. Third, the database does not yet contain many amall-scale and military-related facilities, which may affect the required inspection effort. Fourth, the facility-type ingpection-effort entimates do not take into account the particular features of individual facilities, which can dramatically affect the required safeguards inspection effiort.

Continuing efforte are being made to refine the database. The accuracy of the effort estimates will improve as more information is incorporated on the facilities themeelves and as the verification options cryatallize.

\subsection{Previous Studies}

There have been at least two studies that eatimate the additional safeguards burden on the IAFA that an FMCT wonld entail. One was produced by Broblehaven National Laboratory ${ }^{(2)}$ and the other by the IAFA itaelf ${ }^{(8)}$. The estimates were made based on the number of facilities in the eight designated atates that would be newly aubject to asfeguards and the amount of inspector effort required to safeguard these facilities, based on facility type and on the effort historically needed by the IABA to maintain safeguards that could detect diversion of $1 \mathrm{SQ}$ in a timely manner. Several different options for an inspection regime were assumed in these atudies, ranging from the application of rigorous aafeguards, under the INFCLRC/15s model to more lenient regimes, which would eeek only to verify that unsafeguarded fissile material (not low enriched uranium or fertile material, for example) is not being produced at those facilities that have an inherent capability of doing 80.

Even though the two atudies differed in their detailed assessments of additional inspection effort required and the financial costs for the additional effort, both studies agreed that the required additional resources multiply the current total IAEA safeguards effort by roughly a factor of 2 to 5 . Therefore, it would be usefill to consider how to reduce this additional load upon the international inspectorate and ultimately upon the willingness of member states to finance auch a large increase in IARA ingpection effort. This report also presents several options that might reduce the additional load in the long term.

\subsection{This Study}

This study updates the previous Brookhaven paper and fille in some of the gaps not covered in that study and compares the resulte of that study with a similar effort reported by the IAEA. To perform the yarious spread-sheet calculations, this study uses an updated data bage of facilities in the eight states, as Histed in Table 1. Table 1 includes the numbers of various facility types used for the calculations and includes, for the sake 
of comparison, the numbers of each facility type nged in the previous study ${ }^{(1)}$. Because the updated facility data base is more complete than that used previously, we expect the current results to be more rebable. Purthermore, compartaon of the data in Table 1 shows that the numbers and types of facilities has been rather dynamic. This may or may not continue in the futare.

This stody also assesses one additional option based on a recent (mid-1996) P-5 position. On the one hand, the U.S. and other P-5 members expect reactors (other than plutonium production reactors) and epent fuel to be excluded from eafeguards under the FMCT regine. However, this new option includes an estimate of the inspector effort required for challenge inspections. Since the challenge inspection regime has not yet been defined, the basis for our estimate is, of comrse, open to strbstantial uncertainty. Nonetheless, eince challenge inepections are considered necessary to provide a measure of ageurance in various nations that an FMCT regime can be effective againgt the potential employment of clandestine production facilities some estimate seems required. The estimate included here aseumes that there can be only a limited number per year, based on a quota system or on a priorftized selection process required by limited resources. Further, this option includes the requirement to safeguard MOX facilities and fresh MOX fuel, since the plutonium contained therein will not be protected by a radiation field.

There are various difficulties with challenge inspections, including the need for operators and member states to protect proprietary information from intermational inspectors. The need to protect proprietary information areas exists in routine inspectiong as well. In addition, there is the onus imposed on the inspected party for having aroused suspition in the first place as well as the burden of allowing inspectors enough accese and information to alleviate the concern that resulted in the challenge inspection. Furthermore, the economic burden placed on the inspected party may be subatantial. The supgested eolution ${ }^{(4)}$ is, first, to apply lessons learned in developing the Chemical Weapont Convention (CWC) that make possible the maintenance of appropriate aecrecy while allowing adequate inspection and, second, to "routinize" such inspections, thus removing their onus. (Note that challenge inspections in the CWC permits a substantial period between the request for a challenge inspection and the start of such an inspection.) For example, the regime might specify a quota of two challenge inepections per year per party (among the eight states). This may or may not be viewed as more equitable than, for example, having a finite number of challenge inspections arailable on a cfirst come ftrat served" basis.

Other concerns which relate to challenge inspections is the matter of nondiscrimination, frivolous challenges and the right to request a challenge inspection. It may be argued that a simple quota of two challenge inspections per state-party per year is highly discriminatory against the state parties with fewer facilities or a smaller industrial base opposed to say the United States or Russia. One approach to controlling frivolous challenges would be to require the challenge in cares where the inspection reveals no violation to pay the fall cost of the inepection including that of the inspected party. Note that CWC provides that if the Elective Council finde that the state party requesting a challenge inspection has abused the intent of the CWC, it can recommend that the state partly bear some or all of the finamcial burden of the inspection. A further development of such an approach might require the challenger to post a bond in an amount which wonld approximate these costs. The right to request a challenge inspection might reasonably be limited to the group of eight. This however might be perceived an diseriminatory. Another arrangement wonld permit challenges by all signatories of the 
NPT and yet another would permit guch requesta by the secretariat as well. Inspection effort for challenge inepections is assessed in Section 5 .

\section{Cutoff Convention Options for Routine Verification}

Three options for routine verification effort for the Cutoff Convention are considered. One option entails broad inspection activities very similar to thoes applied under the NPT; a second entaile similar activities but restricts their scope to certain facility typer; the third involves less intensive verification while the fourth is a variation of Option 2 that includes challenge inepection. Facilities to be rontinely verified under these options are shown in Table 2.

In Option 1, the verification regime would include reprocessing plants, enrichment plenta, all civilian reactors, and military reactors (to verify ehutiown). The regime would also include epent fuel storage facilities, MOX fabrication and storage of freeh MOX fuel. Skirting the questions of whether fungibility and co-processing are to be permitted, and whether it would be necessary to verify material control and accountability to levels of I iSQ, or not, the flow and inventory of plutoninm and HEU from both reprocessing and enrichment plants would be verifled and estimates of inspection effort needed would then be baed on typical values for similar facilities in the past, under INFCIRC/153. The objectives of verification would be the detection of diveraion and the detection of undeclared production, particularly from enrichment or reprocessing plants. All peaceful nuclear activities would be declared, including eristing inventories of fiegile material not for military purposes, and all would be rontinely inspected. Shutdown facilities retaining nuclear material would undergo less intensive inspections than operating facilities. Facilities without nuclear material and military facilities with the exception of production reactors would not be declared or be aubjent to routine inspection. Production reactors would be subject to verification of their shut-down statur.

Option 2 preserves the structure of IAEA safeguards but restricts the application to the facilities most relevant to the Cutoff Convention, particularly enrichment and reprocessing plants. The objectives of verification at operating facilities would be the detection of diversion or undeclared production. At ahutdown facilities, the objective would be verification that production is not possible and that none has occurred since the EIF of the Cutoff Convention. All (operational or not) enrichment and reproceseing plants would be declared, as would the research and development facilities capable of the anme operations. Also declared and verified would be facilities storing or procesging highly enriched aranium (HEU) and plutonium produced after the Cutoff Convention's FIF. Facilities procesaing only Iow-enriched uranium (LEU), military facilities, and facilities with aubject fisaile material produced before the EIP of the Cutoff Convention ("grandfathered" material) would not be declared.

Option 3 has narrowly focused routine inspections but broad declarationg. There would be three objectives of verification under this option. Firat is the verification of production and the detection of undeclared production at production facilities. Second is the verification of the disposition of aubject material at storage facilities and processing facilities. Third is the detection of undeclared production at other processing facilities. All nuclear procesaing facilities would be declared, excluding only atorage and military facilities with subject fiseile material produced before the entry-into-force of the Cutoff 
Convention. Table 1 oummerizes the three options. Inspection efforts for these options are reapectively 95,000 peraon-daye of inspection effort (PDI), 29,000 PDI and 10,000 PDI.

The approach to estimating inspection effort outlined above, ignores the problems of detecting clandestine production facilities. For "small" facilities (say, for the sake of argument; -capable of producing meterial for only a few weapons per year), auch as hot cells or (eventually) advaneed laser enrichment facilities, detection would be a eevere challenge. Challenge inspections or international monitoring using environmental sampling are possible options for attempting detection of active facilities of these gorts. The resource requirements for such activities have not been accounted for in either the previous Brookhaven or the IAEA studies. On the other hand, there are etrategieg for savinge in the IARA effort. If EURATOM, for example, rather then IAFA, were to verify compliance by the United Kingdom and France, the cost would be borne by a subset of IAFA member atateg, but not by the IAFA This is not without precedent. Recent changeg in working agreements between the IAFA and BURATOM for current safeguards activities in EURATOM states may gave the IAEA $50 \%$ in inspection effort of member atates of EURATOM. Section 7 containg a brief digmsaion of this aption. Similar arrangemente could be worked out with other subsets of the eight states. Romote 'monitoring has the potential to save some fraction of inspection effort for apent fuel storage ponds and perhaps in safeguarding reactors. Rernote monitoring is further discursed in Section 7.

For bageline comparative purposes using current inspection procedures, this paper employs the assumptions outlined earifer - namely, that inspection effort estimater inciude declared hot cells and challenge inspection, but do not include reactors, unless they use MOX fuel, or apent fuel gtorage. The LAFA atudy referred to in Section 1,2 above asessege a set of somewhat different options denoted as Alternatives $\mathbf{A}, \mathbf{B}, \mathbf{C}$ and $\mathbf{D}$. Alternative A, which is the minimal option, verifies storage of eeparated Pu and HEU, the input and ontput of reproceseing and MOX facilities, enrichment plants capable of producing HEU, and MOX and HEU fueled reactore. Alternative B adds ALL enrichment facilities and calls for material balance verification at inspected facilities Alternative $C$ adds reactors using LEU and natural uranium and irradiated ffasionable material (i.e., spent fuel). Finally, Alternative D, esgentially an INFCIRC/153 regime, adds LEU and fertile material.

The IAEA study provides overall assesements of inspection effort according to facility type, but not according to inspection type. The Brookhaven study provides more detailed assessments of effort required for different aspects of inspections, including physical inventory verifications (PIV), interim inventory verifications (IV), flow verifications (FV) - and the number of each (NIV, NEV) that are required - as a function of the facility type, as histed in Table 3 . Table $\mathbf{3}$ also gives the total annual inspection effort (AIV).

$$
\mathrm{AIE}=\mathrm{PIV}+\mathrm{NIV} * \mathrm{IV}+\mathrm{NFV} * \mathrm{FV}
$$

These quantities are stated in terms of PDI.

Table 1 referred to in Section 1, presents a breakdown for reprocessing plants, enrichment plants, power reactors, production reactors and other. The IAFA paper provides a more detailed breakdown for facilities, including hot cells, MOX facilities and some otherg and the IAEA estimates are ured for each of these facility types. Although the Brookhaven breakdown by facility type is coarser, it is still instructive to compare the two sets of reaplts regerding, specifically, the presence of spent fuel and LEU/natural 
uranium reactora on inspection effort. According to the Brookhaven study, including apent fuel and LEU/natural U reactors (roughly Option 2 versus Option 1, although there are other emall differences between the two definitione of the options):adds about 20\% to the estimated inspection effort. According to the IAEA, looking at Alternative C, with and without spent fuel and reactors, one arrives at a difference of about 25\%. Thil provides some confidence in this relative estimate $-i$,e, with and without spent fuel and reactors.

\section{Facility Information} been ased.

For the current report, both clessified and unclegsified sources of information have

The database containg information about several facility types. These encompass facilities primarily for the production of electric power for civilian needs, those primarily for the production of figaile material for military purposes, and those epecialining in research and development. The facility types are listed in Table 1. Regarding military production fuel cycles, only the resctors, enrichment plants, and reprocessing plants are included in the database at present. Associated fabrication and weapons assemblydisauembly facilities are not yet included. Also absent are such small-scale but important research facilities as hot celle and many shutdown research facilities. For each facility included, the databese has information about status, gross technical features, and the acurces of the information. Inspection effort eatimates desegragated according to facllity itates and country in which they are located are presented in Appendix B. Facilities currently under construction or decommiseioned do not contribute to the inepection effort totals. Inspection effort estimates diagggregated aceording to facility atatus and country of facility location are preaented in Appendix B.

Information about several data elements is lacking for some of the facilities in question here, particularly those in states other than France, the U.K. and the U.S. Indeed, even the exact numbers of facilities associated with the military nuclear fuel cycles are not precisely known.

There is no information in the database yet indicating that certain light-water reactors may be utilizing mixed-oxide (plutonium plus uranium) fresh tuel.

\section{Facility Inapection Effort Characterization}

Table 2 contains the ffort values commengurete with IAWA practice under INFCIRC/153 which were uged for the effort calculations. Values listed are for operating and ahutdown facilities. The inspection effort estimates derive from values typical of factities currently undergoing IAWA safeguards, for which the data are adequate and the verification ayatems generally good. These values characterize Option 1. Values for Options 2 and 3 are derived on the busis of judgment from the Option 1 values.

Precise predictions of actual inspection effort at nuclear facilities depend on a detailed knowledge of facility characteristics, operational statns, and safeguards approach. Additionally important is the State Syetem of Accounting for and Control of Nuclear Material (SSAC), which sets requirementa for the measurement and reporting system of individual facilities. However, facility and SSAC characteristics are not known for all situations addressed here. Nor is there experience with an IAFA safeguards approach for 
some of the facility tJpes. For example, there is no raltable basis for estimating the total ingpection effort that would be required at large gaeeous diffusion enrichment plante, so the values used are somewhat arbitrary.

Another difficult area is that of facilities in various stages of shutdown; obviously thase which are completely inoperable will require less inspection effort than those on "warm standby" or "cold attandby," but these distinctions are not yet captured; each plant requiring inspection effort is now designated either operating or shutdown. (Decommigrioned meane there is no nuclear material.)

The PDI is the most eesily eatimated inspection effort parameter. It is not atraightforward to convert values for PDI to numbers of inspectora required because of the co-location of facilities and because one PDI ean represent a very short time in a facility on a given day or it could represent an inspector present during an entire ahift. A very crude conversion from PDI to dollar cost, which ignores subtleties including coste which are present and which are independent of the number of PDI and which may be gignificant, can be derived from the fact that the IAFA Department of Safoguards conducted 8,200 PDI in 1993 on a Department budget of $\$ 65$ million; this yields a ratio of about $\$ 8,000 / P D I$.

- For a light water reactor (LWR), 3 PDI are required for a PIV, 4 PDI are requifed for all quarterly IIVs; for verification of apent fuel shipments, 2 PDI effort requirement verifications at on-load reactors (OLHs), which are refueled continuously. Monthly IVs are required if the LWR has fresh, mixed-oxide $(M O X)$ fuel present. The totel under Option 1 is 9 PDI for LWRs and 21 PDI for OLRs.

- Plutoninm production reactors with off-load refueling of natural uranium require 6 PDI for a PIV and 8 PDI for each of 8 rofueling (plus spent fuel shipment) campaigns. The total effort would be 70 PDL.

- Critical facilities require increasingly large inspection efforts for the PIV and possibly monthy IVS depending upon the nature of the facility - thermal vs. fast. (A better formulation wonld depend on the amount of nuclear material present). The effort ranges to $15 \mathrm{PDI}$ for the PTV and $2 \mathrm{PDI}$ at each of 11 monthly IIVs for a fast critical facility, for a total of 37 PDI.

- Research reactors require 1 PDI for the PIV and possibly geveral ITVs. For example, monthly IIVa would be needed if there is a large amount of fresh HEU fuel. Very emall regearch reactors would require none. As nged here, the totel effort cocld range from 1 to 12 PDI and depends on the nature of the facility - thermal, fast, or training. A better formulation would depend on the amount of fresh fuel and operational mode.

- Reprocesaing planta in operation require 60 PDI for the PIV, 5 PDI for each of 11 IIVs, and 600 PDI for full-time flow verification (given 200 assumed days of operation) for a total of 935 PDI. Note that this is the largest aingle facilityspecific inspection efrort total. 
- Centrifuge enrichment plents in operation require 25 PDI for the PIV, 2 PDI for each of $5 \mathrm{IV}$, and 4 PDI for flow verification at each of 11 monthly inspections, for a total of $79 \mathrm{PDI}$.

- Gaseous diffusion enrichment plants in operation require 50 PDI for the PIV, 2 .PDI for each of $5 \mathrm{IVs}$, and 4 PDI for flow verification at each of 11 monthly inspections, for a total of 104 PDI.

- Fabrication plante making low-enriched uranium fuel require 60 PDI for the PIV and 4 PDI for each of 5 flow verifications. The total is 80 PDI.

- Conversion plants handing low-enriched uranium require 30 PDI for the PIV and 4 PDI for each of 5 flow verifications. The total is 50 PDI.

- Olier fabrication plants making plutonium or mired oxide fuel without highly automated methods require 60 PDI for the PTV, 25 PDI for each of 11 IIVs, and 400 PDI for two-ebift flow verification, given 200 assumed days of operation, for a total of 735 PDI. The same effort breakdown is assumed to apply to plutonium conversion facilities.

- Very modern fabrication plants making plutonium or mixed oxide fuel by highly automated methods require 60 PDI for the PIV, 15 PDI for each of 11 IIVs, and 15 PDI for each of 11 flow verifications, for a total of 390 PDI.

- The inspection effort for other facilities, including small-scale reproceseing plants and storage facilities is given in the complete summary table included as Appendix A.

This information is summarized in Table 3 . Note that bolk facilities, particularly those processing plutonium, require aubstantially more effort than do facilities euch as resctors, which handle material in item form.

\section{Overall Inspection Effort for Cutoff Convention Verification: BNI Eatimate}

\subsection{Routine Inspection}

For Option 1, the overall inepection effort required is about 35,000 PDI. To put this effirt requirement in perspective, we reiterate that the effort expended by the IAEA for routine safeguards verifications, predominantly in states without nuclear weapons and not including the effort expended for verificatione under UN Security Couneil resolutions, was 8,200 PDI in 1993. For Option 2, the overall inspection effort drops to about 29,000 PDI of inspection, because of the narrower scope of facilities subject to routine verifications. For Option 3, the inspection effort required is about 10,000 PDI of inspection. This effort is much lower than for Options 1 and 2 beceuse of the narrower scope of facilities and the narrower focus of verifications.

The resulta are displayed in Table 1. Each facility group in the table lists the number of facilities in the database followed by the PDI value in the three cases. The first value includes shutdown facilities. 
For all three options, the effort requirament derives predominantly from facilities handling plutonium and highly enriched uranium. Facilities such as light-water reactors require substantially less inspection effort. Reprocessing plants alone account for 60\%, $74 \%$, and $70 \%$ of the inspection effort in the thres cases respectively.

Using the crode cost conversion mentioned in Section 4, the effort estimate of 35,000 PDI for Option I leads to a cost estimate of about $\$ 280$ million. Analogongly, the Option 2 effort estimate of about 29,000 PDI leads to a cost estimate of $\$ 230$ million, while the Option 3 effort estimate of about 10,000 PDI leads to a cost estimate of $\$ 80$ million. The range of inspection effort costs is very large, reflecting the difforences in routine verifications among the three optiong. Note that the loweat effort scenario, Option 8 , results in more than doubling the agency's inspection efiort while Option 1 , with the highegt effort, results in multiplying the current level of inspection expenditures by more than five.

As stated earlier, it is not straightforward to convert valnes for PDI per year to number of inspectors required. However, one can obtain a crude estimate of the number of new inspectors that would be needed from the current stafing lovels at the IAEA. The carrent professional ataff of the three operations (inspections) divisions of the Department of Safeguards numbers about 200; these inspectors account for a yearly total of about 8,200 PDI. Given that the inspection ataff aize is proportional to the annual PDI, the additional inspection ateff needed under the three options are 850,710 , and 240 , respectively. In addition to the monetary expense for these additionsl inspections, bringing these additional inspectors "on line" in a timely manner would be difficult, since there will be a need for recruitment, training and field experience.

It is cless that the PDI totals are mostly driven by the large values of about $\mathbf{9 0 0}$ PDI agaigned to each large reprocessing plant. It may well be that many of these facilities will be shut down by the time the enviention enters into force. However, note that in Option 1 there are about 14,000 PDI assigned to facilities other than reprocessing plants, a value which by itself is $170 \%$ of current IAEA inspection effort. It is also true that amall-scale facilities not included in the database may significantly increase the inspection burden.

For reasons cited throughout the report, the effort estimates are subject to large uncertainties; the reaults therefore are not presented as predictions but as the consequences of alternative assumptions. It is a atraightforward exercise to redo estimates for other verification options and for different facility-specific effort requirements. The facility database will undergo further review and expansion based on clessified information. Finally, the effectiveness of the IAFA verifieation procedures may not be the same for military facilities as for modern civilian facilities, for which safeguards verifications are part of the design considerations.

\subsection{Additional Inspection Bffort Dne to Challenge Inspections}

Challenge inspections would place an additional burden upon the IAEA, but even assuming three such inspections per party per year for the eight states, the additional burden would be relatively minor. Twenty-four inspections of 12 days each, and with 10 ingpectors participating, amounts to 2880 additional PDIs or $\$ 23$ million/year, or just under $\$ 1$ million per challenge inspection. This is roughly a ten per cent efifect. The 
effect of adding challenge inspections on $\mathrm{ADE}$ is shown in Table 4. If 20 inspectors were required, as might be needed if it were necessary to seal a facility around the clock for 7-8 days, as might be done under CWC challenge inspection, the level weuld be $20 \%$ of the total effort, and about 2/3 of the current total IAtA safeguards inspection effort. Additional effort to inspect hot celle only amounts to about 220 PDI's and is thus not significant. Inspecting MOX fuel fabrication facilities adde 2600 PDI'B, which is a ten per cent effect ag well.

Another possibility would be to use special inspections, as foreseen in INFCIRC/153. This type of challenge inspection would not be at convincing to the international community, becaues, under the proviaione in INFCIRC/153, the host nation wonld have to be informed of the inspection and agree to it, allowing for lengthy delays. However, the number of inspectors would be fewer than under CWC challenge inspection rules. Perhape five would suffice, and 8 daye could be sufficient for sample taking. Then, 40 PDI's times 24 inspections would yield 960 PDIs - substantially fewer than in the other case.

An additional option for challenge inspectione might be to use (with the permisaion of the host country) an unmanned aerial surveillance vahicle (UAV) to substitute for the Jarge number of inspectors. The visual or infrared imaging from such a system could, in principle, be relayed in real time through aatellite communications, to, for example, the Vienne HQ of the IAEA. However, the operation and maintenance of this resonrce is costly.

Current estimates for cost of the PREDATOR UAV, which is being used rather euccessfully in Boenia( $(5)$, amount to about a $\$ 8.5$ million purchage price (for two unita with viaugl and infrared capability, satellite control and communications, and ground stations) and $\$ 250$ per air hour operating cost. Eliminating one ground station might be possible and would reduce the cost to about $\$ 6.2$ million. Abont 4000 hours par year could be requtired, amounting to $\$ 1$ million in operating expenses. The cost-benefit tradeoff of a UAV of this type also depends on the period of time over which the acquiaition cost can be amortized. If one aesumed five years, the total cost would be well over \$2 million/year, which might he enough to pay for the additional inspectors who could be replaced on challenge inspections by the UAV syatem. So there may be no advantage to uging UAVa to reduce inspector efiort.

\section{Compariaon of Inspection Effort Eatimates}

\subsection{Summary}

The IAFA and BNL atudies referenced in Section 1.2 above concluded that a rigorous option would require on the order of 25,400 (IAEA) to 35,000 (BNL) PDI per year(6). The rather large difference may be due to a more complete data set available to Brookhaven (which has access to more sources of information for nuclear aites in the P-8 than does the IAEA. Further, some additional types of military facilities are explicttly accounted for in the Brookhaven estimates.) By either estimate, the additional resources for monitoring compliance with an FMCT are enormous. For clarity, the reader is reminded that thts estimate does NOT include any assignment of costs for challenge inspections or other efforts (e.g., environmental monitoring under "98+2") to detect

clandestine facilities. The cost of the additional effort is considered to be between $\$ 140$ 
million/year (1AEA) to $\$ 280$ million/year (Brookhaven)(n). Current IAEA kafeguarde coets are about $\$ 65$ million per year, and have remained essentially constant $t^{(8)}$ gince 1985.

\subsection{IAEA-BNL Estimate Inconsistencies}

There is a puzzle in that while both BNL and IAEA agree that, for 1993, some 8,200 PDIs of inspection effort cost $\$ 65$ million, the IAEA finds that this results in a cost per PDI of $\$ 7,200$.

Further, using the PDI's as accounted for in the IAFA report, one arrives at an implicit assumption of only about $\$ 5600$ per PDI (not \$7200). This is in spite of the fact that the final costs eited include indirect costs and support casts as well (para. 36 of the IAEA report). This difference in estimates, whatever its origin, accounts for most of the difference between the more pessimistic (costly) BNL appraisal and the IAFA acconnting.

Looking more closely at the PDI estimateg, we can diacover, according to the IARA, how large a fraction of the total effort is due to items of interest, such as hot cells, MOX fuel fabrication facilitieg and storage, reactors, and spent fuel storage. The IAFA report breaks down inspection effort clearly among several different types of facilities. It estimates that, for the eight states in question, 2600 PDl's are needed for MOX facilities, $1100 \mathrm{PDI}^{\prime}$ for spent fuel in storage, and 4000 PDI's to inspect reactors. Reactors and spent fuel thus require 5320 PDIs out of a total of 22,100 PDI's required for the LAEA nnder "Alternative C." This alternative includes INFCIRC/159 safeguards for most nuclear facilities, including thase that produce separated and irradiated materials. Low enriched uranium and fertile materials are excluded from the "Alternative $C^{C}$ inspection regime.

Removing the requirement to inspect these facilities reduces the required inspector effort by about $25 \%$. The burden on IAFA would still be considerable, demanding a tripling of effort and resources relative to the current eituation, but including these facilitios would require a quadrupling of effort. Policy makera will have to consider whether the additional expense is worth the effort to safeguard these facilities and materials under an FMCT. However, thare are poasibilities for mitigating costs; these are presented in Section 7.

\section{Opportunities for Eeonomizing on Inspection Resources}

\subsection{Allow IAEA to Act as Auditor of Multilateral Inspectiong}

Under agreements between the IAEA and EURATOM, a good part of the inspection activities of EURATOM member states are made by, and at the expenes of, EURATOM itself. Since two of the eight parties envisioned as targets of the FMCT are also members of FURATOM (the United Kingdom and France), it is conceivable that the cost of inspecting those two countries could be primarily accomplished by and at the expense of EURATOM. This would reduce the burden on IAEA considerably. The IAEA could undertake a monitoring role, in this case (verifying the activities of the FURATOM inspectorate) and save about $50 \%$ of the cost of these inspections $(9)$. However, the fraction of effort devoted to these two countries would constitute about $30 \%$ of the total effort needed to verify an FMCT (10) so a $50 \%$ reduction due to substitution of inspection effort by EURATOM could, in principle, amount to a 15\% reduction in total anfeguards 
effort by the IAEA. Of couree, it is not clear that the rest of the world would necessarily accept this substitution by EURATOM. It is possible that some other nations might suspect a cover-ap of diveraion by the allies of France and the United Kingdom.

An elaboration of this approach might include bilateral ingpections by the US and Rugsio of each others' facilities. There are at least two considerations, as follows:

Firat, the US and Russia might prefer inspections by each other at their sensitive facilitiea compared to having inspectors from the rest of the worid intruding and posaibly deducing information useful for the mannfacture of nuclear weapons. In fact in early analyaes of a possible FMCT during the Cold War, it was considered likely that an agreement and inspections would be more achievable under a bilateral regime than under LAEA safeguards for just this reason. This, of course, depends on whether prolfferation or exposing potential weapons vulnerabilities is the primary concern. Since both have advanced nuclear arsenale, the potential utility of any secrete that leaked to the other party would be problematic. This is not to imply that this would be an insignificant problem.

Second, the effort could be paid for by the U.S. and Rugsia inetead of by the IAEA; since nearly half of the facilities in question are located in these two states (see Table 1), the reduction of IADA effort would be considerable. Of course, the IAEA would have still have to verify the accuracy of the bilateral inspections by audite and apot checks of its own, but the resourees needed for this should be considerabily lese than for the follblown inspextion regime. There is a precedent for the IAFA overseeing bilateral ingpections by two atateg, i.e. the ABACC arrangement between Argentina and Brazil. Again, as for the EURATOM option, the question is whether the rest of the world would accept the US and Russia policing each other.

Taling this approach even further, suppose India and Pakiotan were to inspect each othor as well, with the IAEA ag autitor.

We have now posited three possible bilateral arrangements among the eight countries affected, leaving out only China and Israel. For a rough estimate, if auditing by the IAEA were to cost only $50 \%$ of the total expenditure, and if only China and Inrael were to remain inspected by the IAEA in a complete fashion, some $40 \%$ of the expenditure and effort by the IAEA could be saved. The question at this point is whether Chine and/or Farael would object to this kind of "discrimination."

The ultimate option would be to have all eight countries inspect each other, with the IAEA performing the anditing overgight function only. Then, based on the EURATOM eatimate of aavings amounting to 50\% of the total inspection effort, a ball park eatimate would be that half of the estimated $\$ 140$ million to $\$ 280$ million additional cost of an FMCT could be saved by such an arrangement.

\subsection{IAEA Authentication of U.S. Domestic Safeguards}

United Stated domestic safeguards is a highly developed and offectivo system. Given the magnitude of the U.S. weapons stockpile clandestine activities directed toward augmenting such a stockpile are not credible. Reliance on IAFA anthentication of U.S. aafeguards might be acceptable as a means of substantially reducing IAEA resources 
required for direct FMCT inspections. Note from Table 1 the very aubstential portion of IAWA resources required for inspection of U.S. facilities.

\subsection{Remote Monitoring}

Spent fuel storage ponds and reactors could be monitored in near real time, using remote monitoring Bystems, with the ability to transmit data (including alarms indicating illicit activity) to IAEA headquartars in Vienna or to a regional center out of country. This technique could reduce the required inspection effort constderably. One informal ebtimate has it that from $8 \%$ to $20 \%$ of the IAEA inspection effort could be saved by remote monitoring of this sort. If one were to accept safecuards on spent fuel and reactors, this method could greatly mitigate the $20 \%$ difierential in required jnspection effort for reactors and spent fuel atorage.

\subsection{Spent Fuel}

: Although removel of spent fuel from the category of subject material would reduce the inspection effort needed to verify an FMCT, there are eerious problems with this approach. Firt, the fiegile materials in military apent fuel cannot be "grandfathered" as non-aubject material since it is not eeparated from figrion products at EIF. So military apent fuel is apparently meant to be safeguarded under an FMCT. Why then should civilian spent fuel be exempt since the crucial related problem of finding clandestine hot cells may not be solved convineingly enough to ensure that verification of non-production is adequate?

Above what level toes the radiation field of apent fuel make it self-protecting is an important question yet to be resolved. Only above this level (once determined) can spent fuel be removed from FMCT eafeguard.. One difficulty arises from the low irradiation levels of some fuel notably CANDU fuel, which is only irradiated to about 7500 MWD/tonne, which is far less than the irradiation levels of epent fuel from light water reactors. Another factor is that the radiation field decreases over time, diminishing its protection. The same argument may be made even more strongly for HEU-fueled research reactors, where irradiation is often even less. Military spent fuel is irradiated to only a slightly lesser degree; therefore it may be argued that the quality of the Pu in CANDU fuel is relatively good for weapons purposes. The important isaue of how large the radiation field must be in order for apent fuel to be aelf-protecting, and thus exempt it from FMCT safeguards, is being dealt with elsewhere and will not be considered here.

\section{Conclusions}

The following general conclusions, not including the Cost Savings paragraph, appear to be supported by this study and the two provious studies (References $1 \& 2$ ).

Total Inspection Iffort: The total inspection effort required under an FMCT would, in every case examined, substantially increase compared to the cuxrent resources expended for IAFA safeguards under the NPT. 
All additional inspection efforts would take place in the eight states of current concern (i.e., the P-5, Irrael, India and Pakistan). There appears to be little point in adding obligations (e.g., challenge inspection) to the NPT states at this time although this situation may change in the future. A word of caution is appropriate here. That is that the NPT regime was inadequate to the task of bringing to light the Iraqi program directed toward the development of nuclear weapona. Would NPT verification be adequate to uncover an Iramian nuclear weapons program if one existed?

Up to approximately 20\% of inspection effort could be saved by not doing spent fuel and commercial and research reactors. However, aubatitution of remote monitoring, if implemented, for some of this inspection effort may be a mitigating factor.

MOX Facilities: Contribute ten per cent to the total FMCT inspection effort. ingignificant.

Challenge Inspections: Contribution to the total FMCT inspection effort is almost

Hot Cells: Contribution to the total FMCT inspection effort is almost insignificant.

Cost Savings: Sharing ingpection efforts between the IAEA and the eight nations affected by an FMCT has the potential for very large anvings in inspection effort by the IAEA. (The individual states would provide the bulk of the inspection effort while the IAEA's role would be to audit their efforts for effectiveness.)

Other significant aevinge could come from the use of remote monitoring of spent fuel storage, other static storage areas, and possibly for reactors (not counting the capital investment for hardware and communications to implement such procedures). 


\section{References}

(1) The Text of the Agreement of 18 November 1977 Between the United States of America and the Agency for the Application of Bafecuards in the United Sates of America", INFCIRC/288, IAEA, Dec. 1981.

(2) Ioslie G. Fisbbone and Jomathan Sanborn, "Rontine Ingpection Bffort Required for Verification of a Nuclear Material Production Cutofi Convention," pp 1063-1069, Proceedings of the 36th Annual Meeting of the Inetitute of Nuclear Materials Management, Palm Desert, Californie, July 9-12, 1995.

(3) "A Cutoff Treaty and Associated Coste," An IARA Secreteriat Working Paper presented at a workshop in Toronto, Canada, 17-18 January 1995.

(4) Jack Allentuck, Alan M. Bieber, Leslie G. Fishbone C. Ruth Kempf, Raymond Pargick and Jonathen Semborn, "Options for the Negotiation of Undeclared-Site Inspectione -Under a Cutoff Convention." Brookhaven National Laboratory, S\$N-95-17.

(5) "USAF Agsumes Control of Predator in Bosnia", pg. 80, Defenge Newa, Vol. 11, No. 36, September 9.15, 1996.

(6) This includes safeguarding MOX facilities and declared hot cells, but does not include safeguerds on low enriched uraninm, natural uramium, depleted uranium, and thorium, all of which are "fertile material" i.e., can be used to produce plutonium (or fissile U-293 in the case of thorinm), if irradiated in a reactor. This corresponds to alternative $C$ in the IAEA paper. Low enriched uranium can also be used as feed in a clandestine enrichment facility, which then would need be only half as lerge to produce the same amount of HEU per unit time (relative to a feed of natural uranium, and using the same tails angay).

(7) The Brookhaven eatimate using a less-complete data base (Reference 2) was some 29,000 PDIs corresponding to $\$ 230$ million.

(8) See U.S. Congress, Office of Technology Agseggment, Nuclegr Safeguards and the international Atomic Energy Agency, OTA-IS5-615 (U.S. Government Printing Office, Waghington, D.C., June 1995), p. 18; in 1992 a modest increase was approved, but not realized, since the Soviet Union was unable to meet its payments that year.

(9) See U.S. Congress, Office of Technology Agegesment, op. cit., Reference 5, pg. 51. This refers, in turn, to D. Sehriefer, D. Perricos, and S. Thirratengon, "IAEA Safeguards Fxperience," Symposium Procedings, International Nuclear Safeguards 1994, Narch 14-18, 1994, Vol. 1, p. 40.

(10) For each option, the gum of estinated efforts for inepecting the UK and France is about 30\% of the total estimated effort. See Table 1. 


\section{Acknowledgments}

The anthors are grateful to Maureen Anderson and Maryann Musso for help with manuecript preparation.

\section{Additional Reading}

"Prohibition of the production of fiesile material for nuclear weapons or other nuclear explosive devices," ARES/48/75, United Nations General Assembly, Dec. 16, 1998.

"Fact Sheet-Nonproliferation and Export Control Policy." The White House, Office of the Presa Secretary, Sept. 27, 1993.

"The Structure and Content of Agreements Between the Agency and States Required in Connection with the Treaty on the Non-Proliferation of Nuclear Weapons," NRCIRC/153 (corrected), IAEA, 1972

.Convention on the Prohibition of the Development, Steckpiling and Uge of Chemical Weapons and on Their Destruction", Draft (Final), CD/117s, Conference on Disarmament, Sept. 3, 1992.

"Statute," as amended up to 28 Dec. 1989, IAFA.

"U.S. Fissile Material Initiatives-Implications for the IAFA," R. Einhorn and F. McGoldrick, paper LAEA-SM-383/233 presented by J. Ritch, U.S. Ambassador to the United Natione Organizations in Vienna, at the IAEA Symposium on International Safeguarda, 14-18 March 1994.

"Safeguards Criteria 1991-1995," Dept. of Safeguarde, IAEA; as amended to 4 June 1998.

"Directory of Research Reactors," STIPUB/868, LAFA,1989.

"World Nuclear Industry Handbook,", Nuclear Engineering International, 1993.

"World Nuclear Industry Handbook," Nuclear Engineering International, 1994.

"World Inventory of Plutonium and Highly Enriched Uranium 1992," D. Albright, F. Berhout, and W. Walker, Oxford University Prese, 1993.

"Nuclear Ambitione (The Spread of Nuclear Weapons 1989-1990)," L. S. Spector and J. R. Smith, Westview Press, 1990.

"Nuclear Research Reactors in the World," IAEA-RDS-8/4, IAEA, 1989.

"Nuclear Weapong Databook, Volume V: British, French, and Chinese Nuclear Weapons," A.S. Burrows, R. W. Fieldhouse, and R. S. Norris, Natural Resources Defense Council, Inc. , Westview Press, 1994. 
"Tranaparency Measureg for DOE SNM Production Facilities," J. B. Sanborn, D. M. Gordon, M. 8. Lu, R. Libby, M. H. Ehinger, A. W. Riedy, and B. W. Moran, SSN 98. 7, December 1998.

"Safeguards Manual: Part SMS," TS No. 30, Dept. of Safeguards, LAEA, 1993.

"Ruasian/Soviet Nuclear Warhead Production," NWD 98-1,-T. B. Cochran and R. S. Standish, Natural Restources Defense Couneil, September 1998.

"Nuclear Research Reactors in the World," IAFA-RDS-3/4, IAEA, 1998.

"The Undeclared Bomb," L. S. Spector, Ballinger Publishing Company, 1988.

"Analysis of the Zone Approach for Plutonium Facilities," L.G. Fishbone and T. Teichmann, ISPO-324, Brookhaven National Laboratory, 1991.

"Application of Safeguards to Multiple Facility Fuel Cycles," IAEAISTR-171, IAEA.

. The Annual Report for 1998," IAFA/GCXXXVIII/2, IABA, 1994.

"The Agency's Budget for 1994," IAEA/GCXXXVIV/1062, LAFA, 1993.

Bulletin of the Atomie Sulentists, June 1998

Nuclear Bngineering International, May 1994 and Jume 1994

"Fuel Manufacturing Technology," British Nuclear Fuele, 1991

"FBFC - Nuclear Fuel Fabrication," Societe Fanco-Belge de Fabracation do Combustabiles, 1989. 
Tabte 1.

Inspoution Effion Estimates for Each Verticetion Qption and Numbors of Facilities"

\begin{tabular}{|c|c|c|c|c|c|c|c|c|c|}
\hline & istael & Indita & Pak & us & $W$ & France & Russta & Chivit & Total \\
\hline Reprocessing & 2 & 4 & 3 & $10 \quad 11$ & 3 & 3 & 620 & 3.6 & 24 \\
\hline (1) & 395 & 2805 & $\infty$ & 24102140 & 2805 & 2805 & 29955840 & $\$ 0004705$ & 4574521355 \\
\hline (2) & 395 & 2805 & 60 & 24402140 & 2805 & 2905 & 29955840 & $\$ 10006640$ & 4674621356 \\
\hline (3) & 130 & 900 & Go & 840670 & 900 & 900 & 2901830 & 6901530 & 52907120 \\
\hline Enuichment & 0 & 0 & 1 & 915 & 29 & 20 & $\Leftrightarrow 10$ & 2 & $34 \quad 40$ \\
\hline (1) & 0 & 0 & 79 & $\$ 04392$ & 144207 & 209282 & 380404 & 201 & 1200150 \\
\hline (2) & 0 & 0 & 79 & 204520 & 111 & 200 & 390 & 208 & 19901306 \\
\hline (3) & 0 & 0 & 42 & 200216 & 74 & 104 & 232 & 104 & $7507 \pi$ \\
\hline $\begin{array}{l}\text { Powar' Prod } \\
\text { Reactors }\end{array}$ & 0 & 17 & $\mathbf{z}$ & 164159 & 4851 & 747 & 56 & 87 & 205804 \\
\hline (1) & 0 & $t 50207$ & 21 & $4102+115$ & 760751 & 700704 & 869 & 209158 & aces sots \\
\hline (2) & 0 & 0 & 0 & 0 & 0 & 0 & 0 & 0 & 0 \\
\hline (3) & 0 & 0 & 0 & 0 & 0 & $\mathbf{0}$ & 0 & 0 & 0 \\
\hline Ollher & 3 & I4 13 & 33 & $\$ 17 \quad 249$ & $26 \quad 48$ & 2738 & $48 \quad 48$ & $\begin{array}{ll}43 & 17\end{array}$ & $248 \quad 419$ \\
\hline (1) & 57 & $2402 \times 3$ & $E 60$ & 10081454 & 14901145 & 25462557 & 28642895 & 172053 & 6409 6447 \\
\hline (2) & 0 & 2824 & 0 & 444 741 & $790 \quad 041$ & 20002322 & 22462271 & 6981 & 58706289 \\
\hline (3) & 0 & 40 & o & 80 & 394 & 920 & 900 & 12 & 20502034 \\
\hline Toled & 5 & $32 \quad 34$ & 89 & 28944 & 80111 & $408 \quad 117$ & $\$ 42 \quad 133$ & 832 & $696 \quad 875$ \\
\hline (1) & 452 & 50345043 & 218200 & 47596101 & 49084908 & 69886209 & 67909692 & 25006024 & 2007635145 \\
\hline (2) & 395 & 20002809 & 199 & 29753201 & \$709 3757 & 60005335 & 5440 1293 & $4+644994$ & 28946 \\
\hline (3) & 130 & $904 \quad 900$ & 100150 & 44801154 & 1908 & 1924 & 20002962 & 7461646 & 890810126 \\
\hline
\end{tabular}

"For each factwy type, the first row gives the number of faclilies of a given bype with the stale, end the next three rows indlcale the inspection eflort

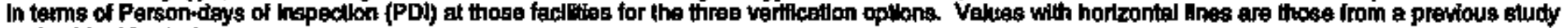
revised in this study. 
Table 2.

- Facilities to Be Routinely Verified Under Cutoff Convention Optiong

Pacility Type

Power Reactora

Pu Production Reactors

Spent Fubl Storage

Rosearch Roectorg and Critieal Fadlitioe

Reprocenaing

Enrichment

Uranimm Fuel Fabrication

Uranium Convarzion

Plntonium Conversion

Plutonium Fudi Pabrteation

Plutonitum and HEU Storage

R\&E Centers (incleding Hot Cella)*

Recovery, Ropurifiention, Fabrication fir Military*
Option I

$\mathbf{x}$

$\mathbf{X}$

$\mathbf{x}$

$\mathbf{x}$

$\mathbf{x}$

$\mathbf{x}$

$\mathbf{x}$

$\mathbf{x}$

$\mathbf{X}$

$\mathbf{x}$

$\mathbf{x}$

$\mathbf{x}$

t

(1)

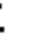

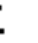

$x$

Option 2

Option 3

$$
\mathbf{X}, 6
$$

d

$\mathbf{p}, \mathbf{a}$

$\mathrm{X}_{,} \mathrm{B} \quad \mathrm{d}$

$\mathbf{X} \quad$ pra

$\mathbf{X} \quad \mathbf{p}, \mathbf{a}$

$\mathbf{x} \quad \mathbf{d}$

$X_{i} \theta$

$x_{,} s \quad d$

$\mathbf{X}$ - Verifientions acsording to IARA Safeguards Criteria

a - Only if subject fiesile material in present

d - Veriffcation of disposition of subject material only

p - Verification of production only

a - Verification of absence of undectared enrichment or reprocegeing

*Very fow in database at preaent

***Not considered in this report 
Table 3.

Facility Inspection Effort Values; PID

\begin{tabular}{|c|c|c|c|c|c|c|c|}
\hline . Type of Pacility" & Options & $\boldsymbol{P W}$ & $I V$ & $\boldsymbol{N a V}$ & $\boldsymbol{F V}$ & NFV & 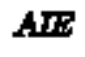 \\
\hline Light watter reactor & 1 & 3 & $\begin{array}{l}1 \\
1\end{array}$ & $\begin{array}{l}4 \\
4\end{array}$ & 1 & $\mathbf{2}$ & $\begin{array}{l}9 \\
4\end{array}$ \\
\hline $\begin{array}{l}\text { Light water reactor with wired-oxide } \\
\text { fresh fuel }\end{array}$ & $\begin{array}{c}1,2 \\
3\end{array}$ & 6 & $\begin{array}{l}1 \\
1\end{array}$ & $\begin{array}{l}11 \\
4\end{array}$ & 1 & $\mathbf{2}$ & $\begin{array}{r}19 \\
4\end{array}$ \\
\hline On-loed reactor & 1 & $\begin{array}{l}7 \\
-\end{array}$ & $\begin{array}{l}2 \\
1\end{array}$ & 4 & 1 & 6 & $\begin{array}{r}21 \\
4\end{array}$ \\
\hline Produetion reactor & I & $\begin{array}{l}6 \\
4\end{array}$ & - & - & 8 & 8 & $\begin{array}{l}70 \\
8\end{array}$ \\
\hline $\begin{array}{l}\text { Critical faclilty: Fast } \\
\text { Geltical facillty: Thermol }\end{array}$ & $\begin{array}{l}1,2 \\
1,2 \\
\end{array}$ & $\begin{array}{l}15 \\
5\end{array}$ & $\begin{array}{l}2 \\
1\end{array}$ & $\begin{array}{l}11 \\
11\end{array}$ & & & $\begin{array}{l}97 \\
16\end{array}$ \\
\hline $\begin{array}{l}\text { Reeasreh reactor: Fast } \\
\text { Regedarch reactor: Thermal } \\
\text { Regearch repctor: Training }\end{array}$ & $\begin{array}{c}1,2 \\
1 \\
1\end{array}$ & $\begin{array}{l}1 \\
1 \\
1\end{array}$ & $\begin{array}{l}1 \\
1\end{array}$ & $\begin{array}{l}11 \\
3 \\
-\end{array}$ & & & $\begin{array}{l}12 \\
4 \\
1\end{array}$ \\
\hline fleprocessing plant & $\begin{array}{c}1,2 \\
3 \\
9\end{array}$ & $\begin{array}{l}60 \\
28 \\
10 \\
\end{array}$ & $\begin{array}{l}25 \\
7 \\
4\end{array}$ & $\begin{array}{l}11 \\
11 \\
5\end{array}$ & $\begin{array}{l}1 \\
1\end{array}$ & $\begin{array}{l}600 \\
200\end{array}$ & $\begin{array}{l}935 \\
900 \\
90\end{array}$ \\
\hline Bnrichment (centrifuge) & $\begin{array}{c}1,2 \\
8 \\
8 \\
\end{array}$ & $\begin{array}{l}25 \\
10 \\
6 \\
\end{array}$ & $\begin{array}{l}2 \\
2 \\
2\end{array}$ & $\begin{array}{l}5 \\
5 \\
5\end{array}$ & $\begin{array}{l}4 \\
2\end{array}$ & $\begin{array}{l}11 \\
11\end{array}$ & $\begin{array}{l}79 \\
48 \\
16 \\
\end{array}$ \\
\hline Entichment (diffusion) & $\begin{array}{c}1,2 \\
3 \\
8\end{array}$ & $\begin{array}{l}50 \\
20 \\
6\end{array}$ & $\begin{array}{l}2 \\
2 \\
2\end{array}$ & $\begin{array}{l}5 \\
5 \\
5\end{array}$ & $\begin{array}{l}4 \\
2\end{array}$ & $\begin{array}{l}11 \\
11\end{array}$ & $\begin{array}{l}104 \\
52 \\
10 \\
\end{array}$ \\
\hline Fabrication (LEU) & 1 & 60 & & & 4 & B & 80 \\
\hline 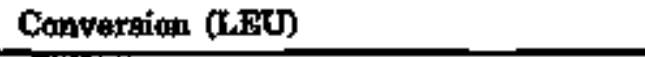 & 1 & 80 & & & 4 & 5 & 50 \\
\hline Fabrleation (MOX, old) \& Pu convervion & $\begin{array}{c}1,2 \\
3 \\
B\end{array}$ & $\begin{array}{l}60 \\
25 \\
10\end{array}$ & $\begin{array}{l}25 \\
15 \\
4\end{array}$ & $\begin{array}{l}11 \\
5 \\
5\end{array}$ & $\begin{array}{l}1 \\
1\end{array}$ & $\begin{array}{l}400 \\
200\end{array}$ & $\begin{array}{l}785 \\
900 \\
30\end{array}$ \\
\hline $\begin{array}{c}\text { Pabrication (MOX, Dew) } \\
\text {. }\end{array}$ & $\begin{array}{c}1,2 \\
8 \\
8\end{array}$ & $\begin{array}{l}60 \\
25 \\
10\end{array}$ & $\begin{array}{l}15 \\
15 \\
4\end{array}$ & $\begin{array}{l}11 \\
6 \\
6\end{array}$ & $\begin{array}{l}16 \\
5\end{array}$ & $\begin{array}{l}11 \\
11\end{array}$ & $\begin{array}{l}290 \\
155 \\
30\end{array}$ \\
\hline
\end{tabular}

"o" denotes shutdown plant ia sll optione, but still with nuclear material or the potential to produce it without extrantinery reconoksuction.

"A fow othorg are not listed hore, including pilobsize facilities to which smaller effort numbers apply 


\section{APPENDIX A: Effort Values}

Eacility Trpe

Light water reactor

On-load reactor

High temperature reactor

Fast breeder reactor

Reactor (other)

Production reactor

Thermal research reactor

Fast research reactor

University reactor

Naval-type reactor

Thermal critical assembly

Fast critical assembly

Natural U conversion

LEU conversion

HEU conversion facility

Plutonium conversion facility

Thorium conversion facility

Natural/depleted U fabrication

LEU fabrication

HEU fabrication

Statos Option 1 Option2 Option 3

o

S

O

$\mathbf{S}$

o

$\mathbf{S}$

$\mathbf{O}$

$\mathbf{s}$

o

$\mathbf{S}$

o

$\mathbf{S}$

o

$\mathbf{S}$

o

$\mathbf{S}$

O

$\mathbf{S}$

o

o

S

o

$\mathbf{S}$

O

S

o

S

o

S

o

S

o

S

O

$\mathbf{S}$

O

$\mathbf{s}$

o

S
9

4

21

4

21

4

21

4

9

4

70

8

4

1

12

4

1

0

12

16

4

37

8

32

10

50

15

735

30

735

30

32

10

52

10

80

30

735

30
0

0

0

0

0

0

0

0

0

0

0

0

0

0

12

4

0

0

12

I6

4

37

8

0

0

0

0

795

30

735

30

0

o

0

0

0

0

735

30
0

0

0

0

0

0

0

0

0

0

0

0

0

0

0

0

0

0

0

4

0

8

0

0

0

0

0

300

30

300

30

o

0

0

0

0

0

300

30 
Facility Type

MOX fabrication (conventional)

MOX fabrication (automated)

Thorium fabrication

Reprocessing (nat. U)

Reprocessing plant (LWU)

Reprocessing plant (HEU)

Reprocessing plant (plutonium)

Reprocessing (thorium)

Reprocessing plant (pilot)

Hot cell (lab scale)

Diffuaion plant

Centrlfuge enrichment plant

Enrichment plant (other)

Sealed storage (spent fuel)

Sealed storage (nat. U)

Sealed storage (HEU)

Sealed storage (plutonium)

Unsealed storage (spent fuel)

Unsealed storage (nat. U)

Ungealed atorage (HEU)
Status Option 1 Option2 Option3

\begin{tabular}{|c|c|c|c|}
\hline 0 & 785 & 735 & 300 \\
\hline $\mathbf{S}$ & 30 & 30 & 30 \\
\hline 0 & 390 & 390 & 155 \\
\hline $\mathbf{s}$ & 30 & $\mathbf{3 0}$ & 30 \\
\hline 0 & 735 & 785 & 300 \\
\hline$s$ & 30 & 30 & 30 \\
\hline 0 & 935 & 935 & 300 \\
\hline $\mathbf{S}$ & 30 & 30 & 30 \\
\hline 0 & 935 & 955 & 800 \\
\hline $\mathbf{S}$ & 30 & $\mathbf{3 0}$ & 30 \\
\hline 0 & 935 & 935 & 300 \\
\hline $\mathbf{S}$ & 30 & 90 & $\$$ \\
\hline 0 & 985 & 935 & 300 \\
\hline $\mathbf{S}$ & 30 & 30 & 30 \\
\hline $\mathrm{O}$ & 935 & 955 & 300 \\
\hline $\mathbf{S}$ & 30 & 3 & 30 \\
\hline 0 & 365 & 365 & 100 \\
\hline $\mathbf{S}$ & 30 & 30 & 30 \\
\hline 0 & 30 & 30 & 30 \\
\hline $\mathbf{S}$ & 12 & 12 & 12 \\
\hline 0 & 104 & 104 & 52 \\
\hline $\mathbf{S}$ & 16 & 16 & 16 \\
\hline $\mathbf{0}$ & 79 & 79 & 42 \\
\hline $\mathbf{S}$ & 16 & 16 & 16 \\
\hline $\mathbf{0}$ & 79 & 79 & 42 \\
\hline $\mathbf{S}$ & 16 & 16 & 16 \\
\hline 0 & 24 & 0 & 0 \\
\hline $\mathbf{S}$ & 4 & 0 & 0 \\
\hline 0 & 12 & 0 & 0 \\
\hline $\mathbf{S}$ & 6 & 0 & 0 \\
\hline 0 & 54 & 54 & 6 \\
\hline $\mathbf{S}$ & $\mathbf{3 2}$ & 38 & 6 \\
\hline 0 & 70 & 70 & 10 \\
\hline $\mathbf{S}$ & 48 & 48 & 10 \\
\hline 0 & 48 & 0 & 0 \\
\hline $\mathbf{S}$ & 8 & 0 & 0 \\
\hline 0 & 24 & 0 & 0 \\
\hline $\mathbf{B}$ & 12 & 0 & 0 \\
\hline 0 & 80 & 80 & 6 \\
\hline $\mathbf{S}$ & 54 & 54 & 6 \\
\hline
\end{tabular}


Eacility Type

Unsealed storage (plutonium)

..

Weapons components fabrication

Weapons assembly/disassembly
Stato

0
$S$
0
$S$
0
$S$
Option 1

120

70

735

30

735

30
120.

70

795

30

785

30
10

10

300

30

300

30 


\section{Appendix B}

B. Statas of Facilities

\section{B.1 Introduction}

Data in this Appendix reports the current facility atatus in the P-5 and T-3. This information is important for inspection planning and assessing the current state of nuclear activities on a country-by-country basis.

\section{B.2 Summary Status Data}

Table B-1 like Table 1, ahow日 the total PDI for the three inspection efforts and type of facilitiea. Additional data are provided on facility status, i.e., operational, under - construction, shutdown, decommissioned.

\section{B.3 Country-by-Country Facility Status}

Tables B-2 to B-9 provide data of facility statns for each of the P-5 and T-3 states.

\section{B.4 "Unknown"}

In the tables referred to ahove, the designation "unknown" is given to facilities that are known to exiat bot where information on their status is lacking. 
Table B-1.

Inspectlon Effort Estmates for Each Veriflcation Option and Numbers of Facillites" by Operational Status

\begin{tabular}{|c|c|c|c|c|c|c|c|}
\hline & Oparationat & $\begin{array}{c}\text { Under } \\
\text { Construction }\end{array}$ & Planned & shitofown & Decommlestoned & $\begin{array}{c}\text { Status } \\
\text { Unknown }\end{array}$ & Tow \\
\hline Reprocessing & 25 & 3 & 0 & 11 & 12 & 1 & 52 \\
\hline (1) & 20,090 & & & 390 & & 995 & 21,355 \\
\hline (2) & 20,090 & & & 390 & & 995 & 21,355 \\
\hline (B) & 6,490 & & & 390 & & 300 & 7120 \\
\hline Enrichment & 26 & 0 & 0 & 14 & 0 & 0 & 40 \\
\hline (1) & 1,314 & & & 208 & & & 1,002 \\
\hline (2) & 1,098 & & & 208 & & & 1,306 \\
\hline (9) & 564 & & & 208 & & & 772 \\
\hline $\begin{array}{l}\text { Powed Prod } \\
\text { Reactors }\end{array}$ & 258 & 22 & 2 & 42 & 40 & 0 & 364 \\
\hline (1) & 3,6003 & & & 216 & & & 9,819 \\
\hline (2) & 0 & & & 0 & & & 0 \\
\hline (3) & 0 & & & 0 & & & 0 \\
\hline Other & 200 & 11 & 2 & 200 & 3 & & 419 \\
\hline (1) & 7,911 & & & 596 & & & 8,447 \\
\hline (2) & 5,840 & & & 442 & & & $6,2,2$ \\
\hline (3) & 2,204 & & & 30 & . & & 2,234 \\
\hline Total & 512 & 36 & 4 & 267 & 65 & 1 & 875 \\
\hline (1) & 32,918 & 0 & 0 & 1,290 & 0 & 935 & 35,143 \\
\hline (2) & 27,028 & 0 & 0 & 980 & 0 & 985 & 28,943 \\
\hline (3) & 9,258 & 0 & 0 & 568 & 0 & 985 & 10,128 \\
\hline
\end{tabular}

"For each facllty type, the first row gives the number of facilites of a glven type within the status, and the next three rows indicate the inspection effort at those faritities for the three verification optlons.

*" See Table B.5. 
Table B-2.

Inspection Effort Estimales for Each Verification Option and Numbers of Facilities* by Operatlonal Status for lsrael

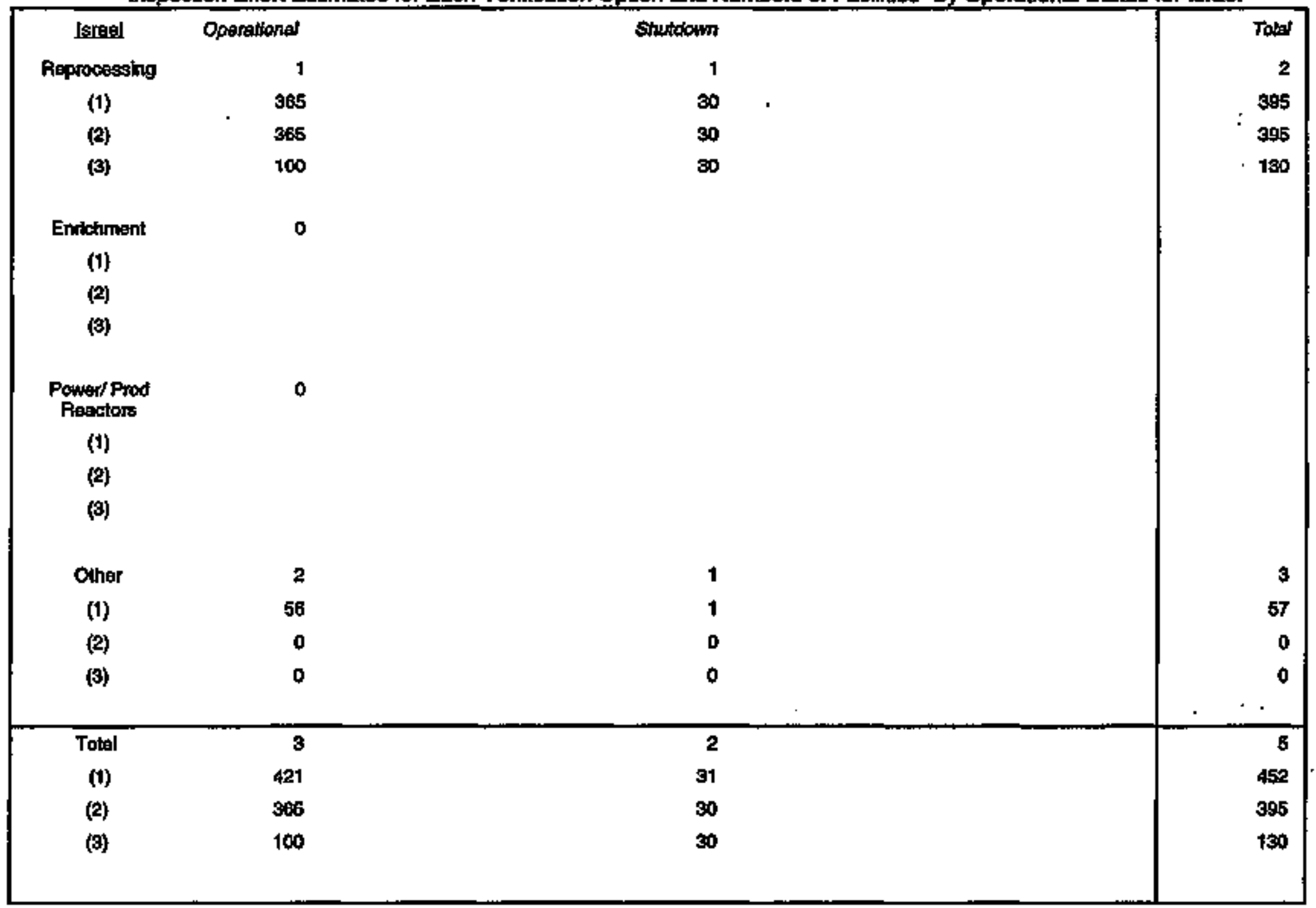

For each faclliy type, the first row gives the number of lacilities of a given type with the status, and the next three rows indicate the inspection effort at those factities tor the three verlitcation options. 
Table B-3.

Inspection Effort Estimates for Each Verification Option and Numbers of Facilities* by Operational Status for india

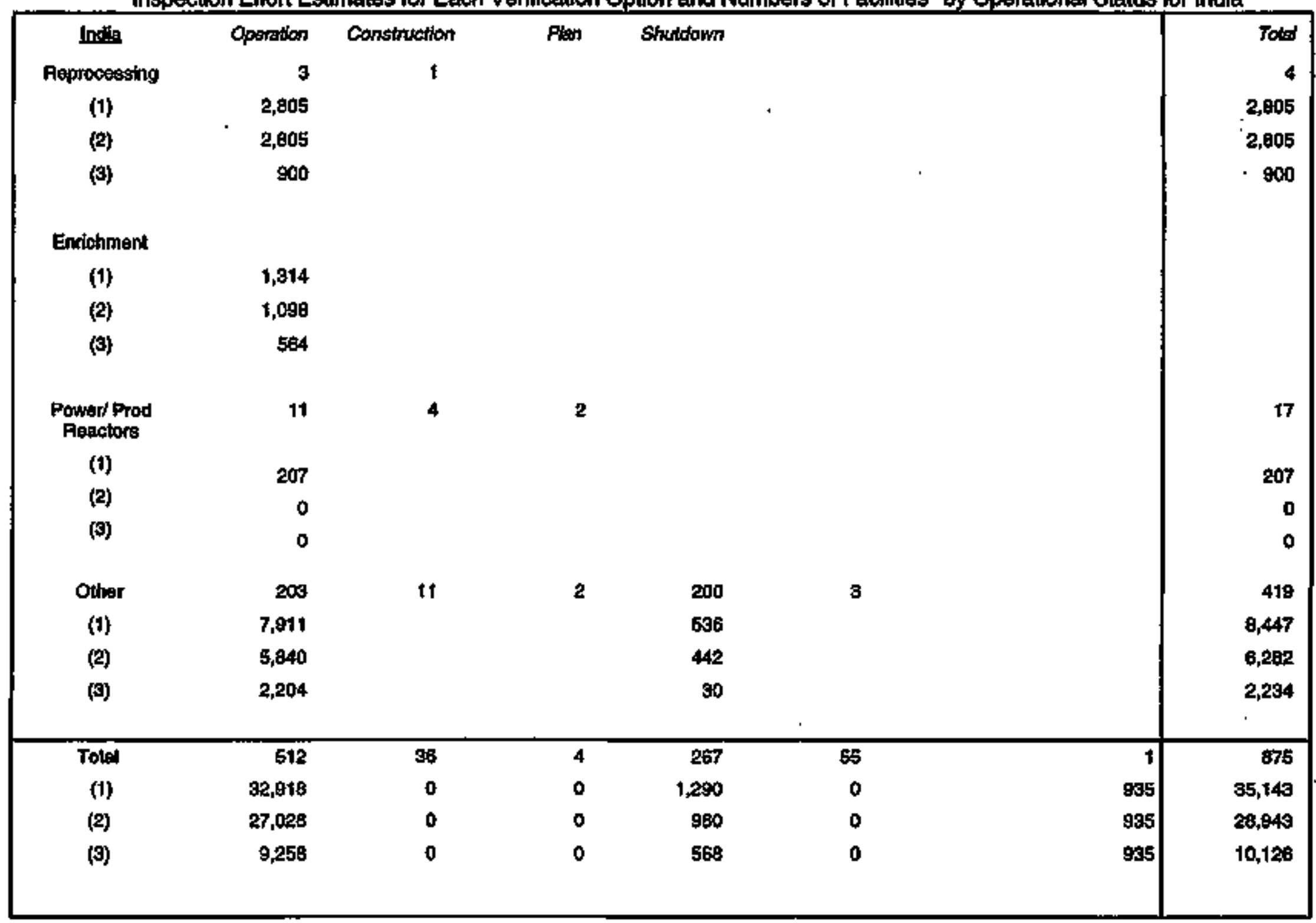

"For each facllly type, the lirst row gives the number of fecitities of a given type within the status, and the next three rows lndlcate the inspection eftort at those factitites for the three verification options. 
Table B-4.

Inspection Effort Estimates for Each Verification Option and Numbers of Facilities" by Operational Status for Pakistan

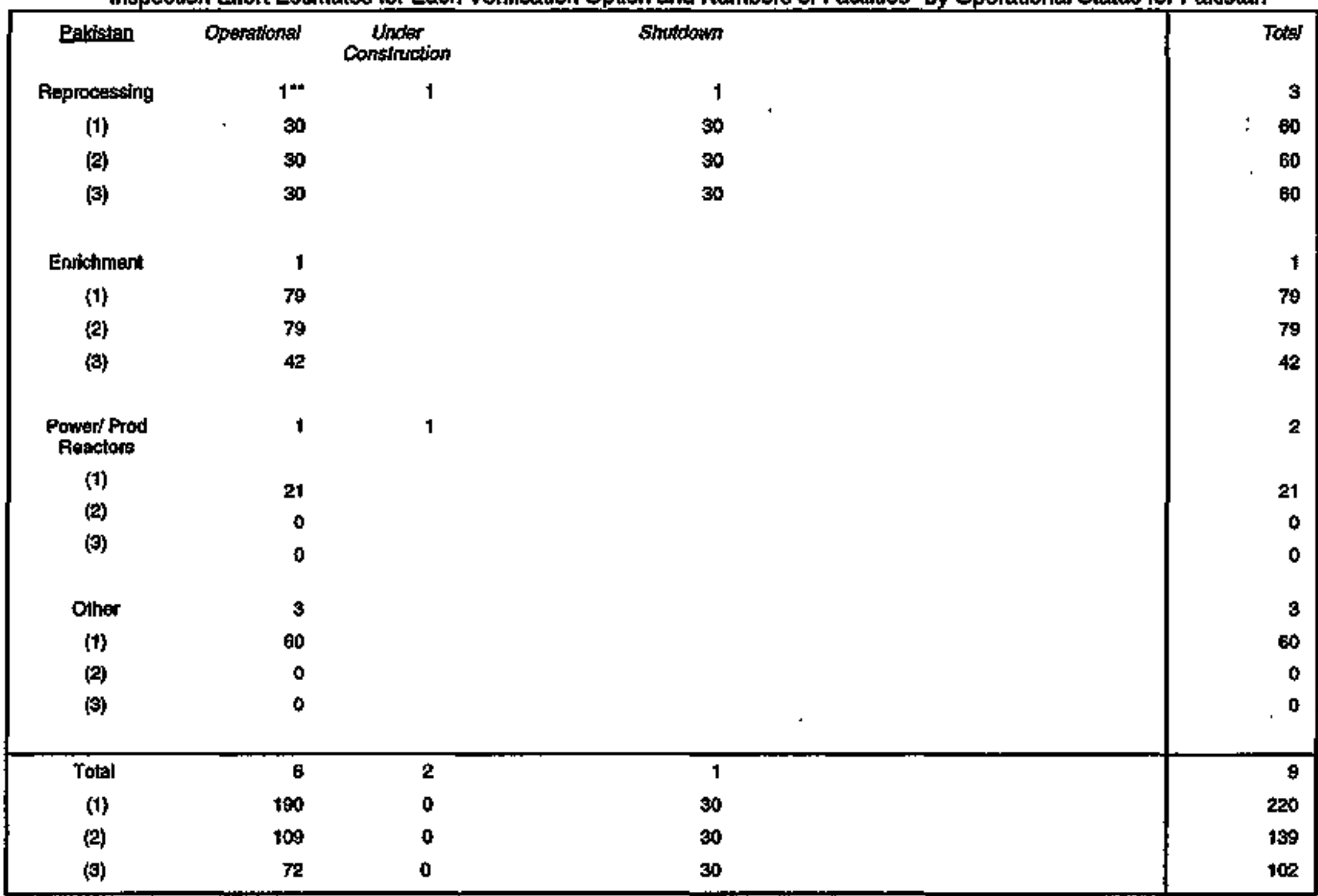

"For each facility type, the first row gives the number of facililies of a glven type within the status, and the next three rowrs indicate lhe inspection effort at those facilties for the three verllication options.

** Hot cenl type 
Tabje B-5.

Inspection Effort Estimates for Each Verification Option and Numbers of Facilities* by Operational Status for USA

\begin{tabular}{|c|c|c|c|c|c|}
\hline Unlled states & Operatianel & $\begin{array}{c}\text { Undior } \\
\text { Construction }\end{array}$ & surtom & Decommisstaned & Total \\
\hline Reprocessing & 2 & & 9 & 0 & 11 \\
\hline (1) & . $\quad 1,870$ & & 270 & & $\cdot 2,140$ \\
\hline (2) & 1,870 & & 270 & & 2,140 \\
\hline (3) & 600 & & 270 & & 870 \\
\hline Enrichment & 7 & & B & & 15 \\
\hline (1) & 280 & & 112 & & 392 \\
\hline (2) & 208 & & 112 & & 320 \\
\hline (8) & 104 & & 112 & & 216 \\
\hline $\begin{array}{l}\text { Powerf Prod } \\
\text { Reactors }\end{array}$ & $\$ 11$ & 7 & 21 & 20 & 159 \\
\hline (1) & 1,011 & & 104 & & $t, 116$ \\
\hline (2) & 0 & & 0 & & 0 \\
\hline (3) & 0 & & 0 & & 0 \\
\hline Other & 94 & 2 & 151 & 2 & 249 \\
\hline (1) & 1,072 & & 389 & & 1,454 \\
\hline (2) & 435 & & 300 & & 741 \\
\hline (9) & 68 & & 0 & & 68 \\
\hline Totad & 214 & 9 & 189 & 这 & 434 \\
\hline (1) & 4,233 & 0 & 866 & 0 & 5,101 \\
\hline (2) & 2,511 & 0 & 690 & 0 & 0,201 \\
\hline (3) & 772 & 0 & 382 & 0 & 1,154 \\
\hline
\end{tabular}

"For each facitity type, the first row gives the number of facilities of a given type within the status, and the next three rows indlcate the inspection effort at those facilities for the three verification options. 
Table B-6.

Inspection Effort Estimates for Verification Options and Numbers of Facillies* by Operalional Status for United Kungtom

\begin{tabular}{|c|c|c|c|c|c|c|}
\hline UK & Operations & $\begin{array}{c}\text { Under } \\
\text { Constrution }\end{array}$ & Planned & Shutdown & Detommissioned & rotas \\
\hline Reprocessing & 3 & & & & & 9 \\
\hline (1) & . $\quad 2,805$ & & & & & 2,805 \\
\hline (2) & 2,805 & & & & & 2,805 \\
\hline (3) & 900 & & & & & 900 \\
\hline Entichment & 7 & & & 2 & & 9 \\
\hline (1) & 175 & & & 32 & & 207 \\
\hline (2) & 79 & & & 32 & & 111 \\
\hline (3) & 42 & & & 32 & & 74 \\
\hline $\begin{array}{l}\text { Power/ Prod } \\
\text { Roactors }\end{array}$ & 35 & & & 6 & 10 & B1 \\
\hline (1) & 728 & & & 28 & & 751 \\
\hline (2) & 0 & & & 0 & & 0 \\
\hline (\$) & 0 & & & 0 & & 0 \\
\hline Other & 14 & 4 & 2 & 27 & 1 & 48 \\
\hline (1) & 1,054 & & & 901 & & 1,145 \\
\hline (2) & 763 & & & 78 & & 841 \\
\hline (3) & 304 & & & 30 & & 394 \\
\hline Total & 59 & 4 & 2 & 35 & 11 & 111 \\
\hline (t) & 4,767 & 0 & 0 & 161 & 0 & 4,908 \\
\hline (2) & 3,647 & D & 0 & 110 & 0 & 3,757 \\
\hline (3) & 1,246 & 0 & 0 & 62 & 0 & 1,308 \\
\hline
\end{tabular}

-For each facilly type, the flrst row glves the number of facilties of a given type within the status, and the next three rows indicate the inspection effort at those facilities for the three verification options. 
Table B-7.

Inspection Effort Estimates for Verfication Options and Numbers of Facilities by Operational Status for France

\begin{tabular}{|c|c|c|c|c|c|}
\hline Emice & Operstionet & $\begin{array}{c}\text { Undier } \\
\text { Canstrietion }\end{array}$ & Shutdown & Decominisstioned & Tots \\
\hline Reprocessing & 3 & & & & 3 \\
\hline (1) & 2,605 & & & & 2,005 \\
\hline (2) & 2,805 & & & & 2,005 \\
\hline (3) & 900 & & & & 900 \\
\hline Enrichment & 3 & & & & 3 \\
\hline (1) & 232 & & & & 232 \\
\hline (2) & 208 & & & & 208 \\
\hline (3) & 104 & & & & 104 \\
\hline $\begin{array}{l}\text { Powed/ Prod } \\
\text { Peactors }\end{array}$ & 58 & 4 & 8 & 3 & 73 \\
\hline (1) & 668 & & 36 & & 704 \\
\hline (2) & 0 & & 0 & & 0 \\
\hline (3) & 0 & & 0 & & 0 \\
\hline Oaher & 25 & 1 & 12 & & 30 \\
\hline (1) & 2,522 & & 35 & & 2,557 \\
\hline (2) & 2,290 & & 3R & & 2,322 \\
\hline (3) & 920 & & 0 & & 920 \\
\hline Total & 89 & 5 & 20 & 3 & 117 \\
\hline (1) & 6,227 & 0 & 71 & 0 & 6,298 \\
\hline (2) & 5,303 & 0 & 32 & 0 & 5,335 \\
\hline (3) & 1,924 & 0 & 0 & 0 & $1, \$ 24$ \\
\hline
\end{tabular}

For each faclity type, the first row gives the number of faclltles of a given type withth the status, and the next three rows indicate the Inspection effort at those facillites for the three verification options. 
Table B-B.

Inspectlon Effort Estimates for Veffilication Options and Numbers of Facillies* by Operational Status for Russia

\begin{tabular}{|c|c|c|c|c|c|}
\hline Bussla & Oparational & $\begin{array}{c}\text { Under } \\
\text { Construetion }\end{array}$ & shutdown & Decamnissioned & Totad \\
\hline Reprocessing & 7 & 1 & & t2 & 20 \\
\hline (1) & . $\quad 5,640$ & & & & $: 5,640$ \\
\hline (2) & 5,640 & & & & 5,640 \\
\hline (3) & 1,030 & & & & 1,030 \\
\hline Enrichment & 6 & & 4 & & 10 \\
\hline (1) & 340 & & 64 & & 404 \\
\hline (2) & 316 & & 64 & & 380 \\
\hline (3) & 168 & & 64 & & 252 \\
\hline $\begin{array}{l}\text { Powert Prod } \\
\text { Ritactors }\end{array}$ & 38 & 3 & 7 & 7 & 55 \\
\hline (1) & 815 & & 48 & & 853 \\
\hline (2) & 0 & & 0 & & 0 \\
\hline (3) & 0 & & 0 & & 0 \\
\hline Other & 40 & 3 & $\mathbf{5}$ & & 40 \\
\hline (1) & 2,674 & & 11 & & 2,685 \\
\hline (2) & 2,265 & & B & & 2,273 \\
\hline (3) & 900 & & 0 & & 900 \\
\hline Total & $\overline{91}$ & 7 & $\overline{16}$ & 19 & 133 \\
\hline (1) & 9,469 & 0 & 123 & 0 & 9,592 \\
\hline (2) & 8,221 & 0 & 72 & 0 & 8,283 \\
\hline (9) & 2,698 & 0 & 64 & 0 & 2,962 \\
\hline
\end{tabular}

"For each facility type, the first row gives the number of facilities of a given type wilthin the status, end the next three rows indicate the inspeclion effort at those facilities for the three verification options. 
Table B-9.

Inspection Effort Estimates for Verification Options and Numbers of Facillites" by Operational Status for China (PRC)

\begin{tabular}{|c|c|c|c|c|c|}
\hline 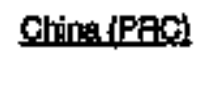 & Oporallonet & $\begin{array}{c}\text { Undir } \\
\text { Construtition }\end{array}$ & Shtudown & Unionown & Total \\
\hline Aeprocessing & 4 & & 1 & 1 & 6 \\
\hline (1) & . $\quad 3,740$ & & 30 & 935 & $: 4,705$ \\
\hline (2) & $\mathbf{3 , 7 4 0}$ & & 90 & 935 & 4,705 \\
\hline (3) & 1,200 & & 30 & 900 & 1,530 \\
\hline Enriçhmęnt & 2 & & & & 2 \\
\hline (1) & 200 & & & & 208 \\
\hline (2) & 200 & & & & 208 \\
\hline (B) & 104 & & & & 104 \\
\hline $\begin{array}{l}\text { Powalf Prod } \\
\text { Reactors }\end{array}$ & 4 & 3 & & & 7 \\
\hline (1) & 158 & & & & t68 \\
\hline (2) & 0 & & & & 0 \\
\hline (3) & 0 & & & & 0 \\
\hline Other & 16 & & $t$ & & $\$ 7$ \\
\hline (1) & 249 & & 4 & & 250 \\
\hline (2) & 77 & & 4 & & 81 \\
\hline (3) & 12 & & 0 & & 12 \\
\hline Total & 26 & 3 & 2 & 1 & 32 \\
\hline (1) & 4,355 & 0 & 34 & 905 & 5,324 \\
\hline (2) & 4,028 & 0 & 34 & 935 & 4,994 \\
\hline (3) & 1,316 & 0 & 30 & $\$ \infty 0$ & 1,646 \\
\hline
\end{tabular}

"For each facithy type, the first row glves the number of facititles of a given type within the stalus, and the next three rows tndlcate the laspection effort at those facilities for the three verification options. 